\title{
Melatonin-Induced Changes in Cytosolic Calcium Might be Responsible for Apoptosis Induction in Tumour Cells
}

\author{
Barbora Chovancova ${ }^{a}$ Sona Hudecova ${ }^{a} \quad$ Lubomira Lencesova ${ }^{a}$ Petr Babulab \\ Ingeborg Rezuchova ${ }^{c}$ Adela Penesova ${ }^{a}$ Marian Grman ${ }^{a}$ Roman Moravcik ${ }^{d}$ \\ Michal Zeman ${ }^{d} \quad$ Olga Krizanova ${ }^{a}$ \\ aInstitute of Clinical and Translational Research, Biomedical Research Center, Slovak Academy of \\ Sciences, Bratislava, Slovakia, 'Department of Physiology, Faculty of Medicine, Masaryk University, \\ Brno, Czech Republic, Institute of Virology, Biomedical Research Center, Slovak Academy of Sciences, \\ Bratislava, Slovakia, 'Department of Animal Physiology and Ethology, Faculty of Natural Sciences, \\ Comenius University, Bratislava, Slovakia
}

\section{Key Words}

Melatonin • Apoptosis • ER-stress • Cancer • Calcium • Reactive oxygen species

\begin{abstract}
Background/Aims: Melatonin is a hormone transferring information about duration of darkness to the organism and is known to modulate several signaling pathways in the cells, e.g. generation of endoplasmic reticulum stress, oxidative status of the cells, etc. Melatonin has been shown to exert antiproliferative and cytotoxic effects on various human cancers. We proposed that this hormone can differently affect tumour cells and healthy cells. Methods: We compared the effect of $24 \mathrm{~h}$ melatonin treatment on calcium transport (by fluorescent probes FLUO-3AM and Rhod-5N), ER stress (determined as changes in the expression of CHOP, XBP1 and fluorescently, using Thioflavin T), ROS formation (by CellROX ${ }^{\circledR}$ Green/Orange Reagent) and apoptosis induction (by Annexin-V-FLUOS/propidiumiodide) in two tumour cell lines ovarian cancer cell line A2780 and stable cell line DLD1 derived from colorectal carcinoma, with non-tumour endothelial cell line EA.hy926. Results: Melatonin increased apoptosis in both tumour cell lines more than twice, while in EA.hy926 cells the apoptosis was increased only by $30 \%$. As determined by silencing with appropriate siRNAs, both, type 1 sodium/ calcium exchanger and type $1 \mathrm{IP}_{3}$ receptor are involved in the apoptosis induction. Antioxidant properties of melatonin were significantly increased in EA.hy926 cells, while in tumour cell lines this effect was much weaker. Conclusion: Taken together, melatonin has different antioxidative effects on tumour cells compared to non-tumour ones; it also differs in the ability to induce apoptosis through the type 1 sodium/calcium exchanger, and type $1 \mathrm{IP}_{3}$ receptor. Different targeting of calcium transport systems in tumour and normal, non-tumour cells is suggested as a key mechanism how melatonin can exert its anticancer effects. Therefore, it might have a potential as a novel therapeutic implication in cancer treatment.
\end{abstract}




\section{Cellular Physiology Cell Physiol Biochem 2017;44:763-777 \\ \begin{tabular}{l|l|l} 
and Biochemistry Published online: November 23, 2017 & $\begin{array}{l}\text { C } 2017 \text { The Author(s). Published by S. Karger AG, Basel } \\
\text { www.karger.com/cpb }\end{array}$
\end{tabular} \\ Chovancova et al.: Melatonin and Cancer}

\section{Introduction}

Melatonin (N-acetyl-5-methoxytryptamine) is a hormone primarily produced by the pineal gland, which displays characteristic daily and seasonal patterns of secretion, and plays an important role in sleep regulation $[1,2]$. Large number of studies has demonstrated the protective role of melatonin and its metabolites against free radicals and oxidative stress [3-5]. Thus, melatonin acts as an antioxidant by scavenging free radicals and increasing the activity of antioxidant enzymes in the body. Melatonin has been consistently shown to suppress formation of reactive oxygen/nitrogen species (ROS/RNS) at the mitochondrial level, thereby protecting against oxidative or nitrosative damage to electron transport chain proteins. Moreover, it also limits lipid peroxidation in the inner membrane, thus favouring electron flux and ATP (adenosine triphosphate) production [6].

Melatonin has also been shown to exert antiproliferative and cytotoxic effects on human cancers, including colorectal cancer [7], neuroblastoma [8], hepatocarcinoma [9], lung cancer [10-12], breast cancer [13], prostate cancer [14, 15], and leukaemia [16, 17]. In a gastric cancer cell line it was already shown that proapoptotic effect of melatonin could be due to activation of a Caspase-dependent pathway and inhibition of the nuclear translocation of NF- $\mathrm{BB}$ p65, two processes that are regulated by p38 and c-Jun N-terminal kinase (JNK) [18]. Nevertheless, in human MG-63 osteosarcoma cells melatonin's antiproliferative action was mediated by inhibition of the extracellular signal-regulated kinase (ERK1/2) signalling pathway rather than the p38, JNK, or Akt pathways [19]. However, the precise molecular mechanisms of melatonin action in cancer cells are still under investigation.

Several factors contribute to the mechanisms that make melatonin an interesting compound for targeting cancer cells. Among these, endoplasmic reticulum (ER) stress is of special importance. Previous studies have demonstrated that the ER is responsible for protein folding and trafficking, lipid synthesis, and the maintenance of calcium homeostasis in the cell. Melatonin acts cooperatively with ER stress to promote the apoptosis of cancer cells or inhibits ER stress to attenuate chemotherapy-associated side effects and chemoresistance. In rats with diethylnitrosamine-induced hepatocarcinogenesis, melatonin treatment significantly increases the expression of activating transcription factor 6 (ATF6), C/EBP homologous protein (CHOP), and binding immunoglobulin protein (BIP), which might further promote the incidence of apoptosis [20]. Apoptosis derived from unresolved ER stress has also been observed, indicating that a sustained ER stress response could contribute to tumour cell death [21]. Resistance to cell death is a distinctive characteristic of cancer. Apoptosis is one of the main mechanisms implicated in cell death, and its inactivation contributes to tumour progression and chemotherapy resistance [22]. Proapoptotic effects of melatonin [23, 24], and its effects in combination with ER stress inducers (e.g. tunicamycin) have been reported in different hepatocellular carcinoma cell lines [25]. Interestingly, melatonin has been shown to induce apoptosis under ER stress conditions in hepatoma cells via induction of C/EBP homologous protein (CHOP) and suppression of cyclooxygenase 2 (COX-2) [25]. Melatonin exerts antimetastatic effects on liver and breast cancers and also inhibits matrix metalloproteinase (MMP) activity [26].

Calcium is an important signalling molecule that modulates a variety of processes, including the induction of apoptosis. Moreover, depletion of calcium from the ER is an important feature of ER stress. The role of calcium in the action of melatonin is only partially elucidated. Melatonin reduces $\mathrm{Ca}^{2+}$ release and modulates the pancreatic responses induced by cholecystokinin-8 (CCK-8), which might be explained by the stimulation of $\mathrm{Ca}^{2+}$ transport from cells through the plasma membrane and subsequent $\mathrm{Ca}^{2+}$ reuptake into the endoplasmic reticulum $[27,28]$. Melatonin might exert protective effects against oxidative stress, cytosolic calcium overload and mitochondrial damage in dexamethasone-induced neurotoxicity [8].

Based on this knowledge, we aimed to compare the proapoptotic effect of melatonin on tumour versus normal cell lines, examining its impact on ER stress, its induction of apoptosis and its antioxidant effects. Moreover, we studied the involvement of calcium and some calcium transporters (especially those that are known to be involved in the process of 


\section{Cellular Physiology Cell Physiol Biochem 2017;44:763-777 and BiOChemistry Published onlIne: November 23, 2017 \begin{tabular}{l|l} 
DOI: 10.1159/000485290 2017 The Author(s). Published by S. Karger AG, Basel \\
www.karger.com/cpb
\end{tabular}}

Chovancova et al.: Melatonin and Cancer

apoptosis - type 1 sodium/calcium exchanger (NCX1) [29, 30] and type 1 IP $_{3}$ receptor [31]) in melatonin-induced apoptosis.

\section{Materials and Methods}

\section{Cell lines and treatment}

Experiments were performed on ovarian cancer cell line A2780 (Sigma Aldrich, USA), stable cell line derived from colorectal carcinoma DLD1 (Sigma Aldrich, USA) and endothelial EA.hy926 cell line (ATCC® CRL-2922 ${ }^{\mathrm{TM}}$ ). Ovarian carcinoma cells and colon adenocarcinoma cells were incubated in RPMI-1640 medium (Sigma Aldrich, USA), supplemented with $2 \% \mathrm{~L}$-glutamine and $\mathrm{NAHCO}_{3}, 10 \%$ fetal bovine serum, and penicillin/streptomycin antibiotics. EA.hy926 cells were incubated in DMEM medium, supplemented with $2 \%$ L-glutamine, $10 \%$ fetal bovine serum, and penicillin/streptomycin antibiotics. Cells were cultured in humidified atmosphere at $37^{\circ} \mathrm{C}$ and $5 \% \mathrm{CO}_{2}$. After plating, cells were treated for $24 \mathrm{~h}$ with melatonin (Sigma Aldrich, USA) in a final concentration 0.1, 1.0, and $10 \mu \mathrm{M}$.

\section{Analysis of the gene expression by real-time PCR}

Total RNA was isolated using TRI Reagent. Reverse transcription was performed using $1.0 \mu \mathrm{g}$ of total RNAs and Ready-To-Go You-Prime First-Strand Beads with the pd(N6) primer (GE Healthcare Life Sciences, UK). The real-time PCR amplification and detection was carried out on the Applied Biosystems StepOneTM RealTime PCR Systems (Applied Biosystems, USA). SYBR Green Master Mix with ROX reference dye (ThermoFischer Scientific, USA), primers $(10 \mathrm{pmol})$ and the reverse transcription product were mixed to a final volume of $10 \mu \mathrm{l}$. Master Mix with primers and template was separately loaded onto 96 -well and 48well plates. Plates were centrifuged to remove air bubbles in the wells. The PCR protocol consisted of $10 \mathrm{~min}$ $95^{\circ} \mathrm{C}$ initial denaturation, followed by 40 repeats of $15 \mathrm{~s} 95^{\circ} \mathrm{C}$ denaturation and $1 \mathrm{~min} 60^{\circ} \mathrm{C}$ annealing/ elongation. The expression of target genes type 1 sodium-calcium exchanger (NCX1), inositol trisphosphate receptor type $1\left(\mathrm{IP}_{3} \mathrm{R} 1\right)$, inositol trisphosphate receptor type $2\left(\mathrm{IP}_{3} \mathrm{R} 2\right)$, inositol trisphosphate receptor type $3\left(\mathrm{IP}_{3} \mathrm{R} 3\right.$ ), plasma membrane $\mathrm{Ca}^{2+}$ ATPase (PMCA), CHOP, X-box binding protein 1 (XBP1) was normalized to the expression of housekeeping gene $\beta$-actin. For detection of $\beta$-actin, NCX1, PMCA and IP ${ }_{3}$ R1the following primers were designed: human $\beta$-actin: 5'- ACA TCT GCT GGA AGG TGG AC- 3' (forward); 5'- TCC TCC CTG GAG AAG AGC TA - 3' (reverse); human NCX1: 5'- TCC CAT CTG TGT TGT GTT CGC - 3' (forward); 5' - TCA TCT TGG TCC CTC TCA TC - 3' (reverse); human PMCA: 5'- GTG AAG GCA GTG ATG TGG G - 3' (forward); 5'- CTT CAT CAT AGT GCG TGA GAT - 3' (reverse); human IP R1: 5'- TCT ATG AGC AGG GGT GAG ATG AG - 3' (forward); 5'- GGA ACA CTC GGT CAC TGG AT - 3' (reverse) [32]. For detection of IP ${ }_{3} \mathrm{R} 2$, IP ${ }_{3} \mathrm{R} 3, \mathrm{CHOP}, \mathrm{XBP} 1$ expression the following primers were used: human IP R2: 5' - ATG CGT GTG TCC TTG GAT GC - 3' (forward) [33]; 5'- GTA GCA GAA GTA GCT GAT TG - 3' (reverse) [33]; human IP ${ }_{3}$ R3: 5'- AGT GAG AAG CAG AAG AAG G - 3' (forward) [34]; 5'- CAT CCG GGG GAA CCA GTC - 3' (reverse) [34]; human CHOP: 5'- GGA GCT GGA AGC CTG GTA TGA GG - 3' (forward) [35]; 5'- TCC CTG GTC AGG CGC TCG ATT TCC - 3' (reverse) [35]; human XBP1: 5'- CTG AGT CCG CAG CAG GTG- 3' (forward) [36]; 5'- AGT TGT CCA GAA TGC CCA ACA - 3' (reverse) [36].

\section{Western blot analysis}

Cells were scraped and resuspended in $10 \mathrm{mM}$ Tris- $\mathrm{HCl}, \mathrm{pH} 7.5,1 \mathrm{mM}$ phenylmethyl sulfonylfluoride (PMSF, Serva, Heidelberg, Germany), protease inhibitor cocktail tablets (Complete EDTA-free, Roche Diagnostics, Mannheim, Germany) and subjected to centrifugation for $10 \mathrm{~min}$ at $3000 \mathrm{x} \mathrm{g}$ at $4^{\circ} \mathrm{C}$. The pellet was resuspended in Tris-buffer containing the $50 \mu \mathrm{M}$ CHAPS (3-[(3-cholamidopropyl)dimethyl-ammonio]1-propanesulfonate, Sigma Aldrich, USA), and then incubated for $20 \mathrm{~min}$ at $4^{\circ} \mathrm{C}$. Protein concentration in lysate was determined by the method of Lowry et al. [37]. 5-90 $\mu \mathrm{g}$ of protein extract from each sample was separated by electrophoresis on $8-16 \%$ and $4-12 \%$ SDS polyacrylamide gradient gels (Amersham Biosciences, UK), and proteins were transferred to the Hybond-PVDF membrane (Amersham Biosciences, UK) using semidry blotting (Owl, Inc., USA). Membranes were blocked in 5\% non-fat dry milk in TrisBuffered Saline with Tween 20 (TBS-T) overnight at $4^{\circ} \mathrm{C}$ and then incubated for $1 \mathrm{~h}$ with appropriate primary antibody. Following washing, membranes were incubated with secondary antibodies to mouse or rabbit IgG conjugated to horseradish peroxidase for $1 \mathrm{~h}$ at room temperature. An enhanced chemiluminiscence 


\section{Cellular Physiology Cell Physiol Biochem 2017;44:763-777 \begin{tabular}{l|l|l} 
DOI: 10.1159/000485290 & $\begin{array}{l}\text { O 2017 The Author(s). Published by S. Karger AG, Basel } \\
\text { www.karger.com/cpb }\end{array}$
\end{tabular}}

Chovancova et al.: Melatonin and Cancer

detection system (LuminataTM Crescendo Western HRP Substrate, Millipore) was used to detect bound antibody. The optical density of individual bands was quantified using PCBAS 2.0 software. Antibodies raised against the following proteins were used: rabbit polyclonal antibody to NCX1 ( $\pi 11-13$, Swant, Bellizona, Switzerland), mouse monoclonal antibody to $\beta$-actin (Abcam, Cambridge, UK) and rabbit polyclonal antibody to $\mathrm{IP}_{3} \mathrm{R} 1$ (Sigma, USA).

\section{Determination of the levels of cytosolic $\left[\mathrm{Ca}^{2+}\right]_{i}$ by Fluo-3AM fluorescent dye}

This method was already described in Lencesova et al. [38]. Briefly, A2780, DLD1, and EA.hy926 cells were plated on 24-well plate at density of $4 \times 10^{4}$. After $24 \mathrm{~h}$ of treatment, cells were washed with $1 \mathrm{ml}$ of serum-free medium and loaded with $2 \mu \mathrm{M}$ Fluo-3AM (4-(6-acetoxymethoxy-2, 7-dichloro-3-oxo9-xanthenyl)-4'-methyl-2, 2'(ethylendioxy)dianiline-N,N,N',N'-tetraacetic acid tetrakis (acetoxy methyl) ester) (Sigma-Aldrich, USA) in the presence of 0.5\% pluronate (Sigma-Aldrich, USA) in serum-free medium, for $30 \mathrm{~min}$ at $37^{\circ} \mathrm{C}, 5 \% \mathrm{CO}_{2}$, in dark. Afterwards, cells were washed with $1 \mathrm{ml}$ of serum-free medium, and fluorescence was measured on the fluorescence scanner (BioTek, Germany) at $\lambda_{\mathrm{ex}} 560 \mathrm{~nm}$ and $\lambda_{\mathrm{em}} 526 \mathrm{~nm}$. Results were calculated as the arbitrary units of fluorescence.

\section{Fluorescence}

Cells were plated on poly-L-lysine (10 mg mL-1; Sigma-Aldrich, St. Luis, MD, USA)-coated coverslips in Sarstedt 24 -well plates in $1 \mathrm{~mL}$ of medium with $10 \%$ of fetal bovine serum and mixture of streptomycin and penicillin. Cells were incubated in a humidified atmosphere of $5 \% \mathrm{CO}_{2}$ air at $37^{\circ} \mathrm{C}$. After the melatonin treatment, cells were washed three times with $1 \mathrm{ml}$ of $0.1 \mathrm{M}$ PBS (phosphate buffers saline, pH 7.4). Cell ROX Green reagent (Invitrogen, USA) was used to visualize ROS. The cells were stained with reagent (5 Q M) and incubated at $37^{\circ} \mathrm{C}$ for $30 \mathrm{~min}$. Afterwards, cells were washed with PBS. The intensity of CellROX Green fluorescence is proportional to the level of free radical oxidation. In order to determine ER stress, Thioflavin $\mathrm{T}$ in PBS at a final concentration $50 \mu \mathrm{M}$ was used according to procedure described by Beriault and Werstuck [39]. Hoechst 33258 (50 $\mu$ g.ml- ${ }^{-1}$, Sigma Aldrich, USA) was used to counterstain nuclei. All specimens were imaged on Nikon Eclipse Ti-S/L100 epifluorescence microscope equipped with appropriate set of excitation and emission filters (Nikon, Japan).

\section{Immunofluorescence}

EA.hy926 and DLD1 grown on glass coverslips were fixed in ice-cold methanol. Non-specific binding was blocked by incubation with PBS containing 3\% BSA for 60 min at room temperature. Cells were then incubated with primary antibody diluted in PBS with $1 \%$ BSA for $1 \mathrm{~h}$ at $37^{\circ} \mathrm{C}$. In these experiments, the antiNCX1 rabbit polyclonal antibody p11-13 (1:200 dilution, Swant, Switzerland) against the full length canine cardiac NCX1 was used. This antibody recognizes all splice variants of NCX1, does not cross react with other NCX isoforms. Afterwards, cells were washed four times with 1xPBS with 0.02\% TWEEN (Sigma Aldrich, USA) for $10 \mathrm{~min}$, incubated with Alexa Fluor-488 donkey anti-rabbit IgG (1:1000 dilution, Thermo Fisher Scientific, USA) in PBS-BSA for $1 \mathrm{~h}$ at $37^{\circ} \mathrm{C}$ and washed as previously. Also, to determine type $1 \mathrm{IP}_{3}$ receptor mouse monoclonal antibody to synthetic peptide, corresponding to amino acids near the $\mathrm{C}$-terminus of the $\mathrm{IP}_{3}$ receptor (1:100 dilution, Calbiochem, Darmstadt, Germany) was used. Cells were washed four times with 1xPBS with $0.02 \%$ TWEEN (Sigma Aldrich, USA) for $10 \mathrm{~min}$, incubated with Alexa Fluor-594 goat anti-mouse IgG (1:1000 dilution, Thermo Fisher Scientific, USA) in PBS-BSA for $1 \mathrm{~h}$ at $37^{\circ} \mathrm{C}$ and washed as previously. Finally, cells were mounted onto slides in mounting medium with DAPI (Sigma Aldrich, USA), analyzed by fluorescence microscopy (Axio Scope.A1, Zeiss, Germany) using EC Plan-Neofluar 100x/1.3 oil objective. Images of all samples were acquired at the same microscope setup.

\section{Detection of apoptosis with Annexin-V-FLUOS}

After the melatonin treatment, A2780, DLD1, and EA.hy926 cells were gently scraped and pelleted at $100 \mathrm{x}$ g for $5 \mathrm{~min}$. Cells were then washed with $1 \mathrm{ml}$ of PBS and cell pellet was resuspended in $200 \mu \mathrm{l}$ of Annexin-V-FLUOS/propidium iodide labeling solution (Roche Diagnostics, USA) and incubated at a room temperature in dark for 20 min according the manufacturer's protocol. After the incubation, samples were diluted with $400 \mu \mathrm{l}$ PBS, placed on ice and measured on BD FACSCanto II flow cytometer (Becton Dickinson, Ann Arbor, USA).

\section{KARGER}


Cellular oxidative stress by CellROX® Orange Reagent

Cellular oxidative stress was considered by measuring of ROS using CellROX® Orange Reagent (Thermo Fisher Scientific, USA). Cells were plated $24 \mathrm{~h}$ before the experiment in 24 well plates. After that, cells were treated by different concentrations of melatonin $(10 \mu \mathrm{M}, 1 \mu \mathrm{M}$, and $100 \mathrm{nM})$ for $24 \mathrm{~h}$ in serum free medium. As a positive control, pyocyanine was used ( $50 \mu \mathrm{M}$ for $4 \mathrm{~h}$, Sigma Aldrich, USA). Treated cells were washed with serum free medium and incubated with CellROX® Orange Reagent at $5 \mu \mathrm{M}$ final concentration in well for $30 \mathrm{~min}$ at $37^{\circ} \mathrm{C}$ in the dark in $\mathrm{CO}_{2}$ incubator. After removing of fluorescent dye, cells were washed twice with 1x PBS (pH 7.4) and fluorescence was measured at $545 \mathrm{~nm}$ excitation and $565 \mathrm{~nm}$ emission wavelength on Synergy fluorescence reader (BioTec, Germany). Results were expressed as fluorescence arbitrary units.

\section{Gene silencing}

Cells were grown in 6-well plates in RPMI with 10\% FBS. Transfection of siRNAs was performed with DharmaFECT1 transfection reagent (Dharmacon, Thermo Scientific, USA) as described previously Hudecova et al. [40]. ONTARGET plus SMART pool human ITPR1 and NCX1 siRNAs (Dharmacon, Thermo Scientific, USA) were applied to the final concentration of $100 \mathrm{pmol}$ per well for $48 \mathrm{~h}$. The same procedure was performed with ON-TARGET plus Non-targeting Pool, which serves for the determination of baseline cellular responses in RNAi experiments. Silencing was performed for $48 \mathrm{~h}$. After the first $24 \mathrm{~h}$ of silencing, melatonin $(10 \mu \mathrm{M})$ was applied for additional $24 \mathrm{~h}$. All groups of cells were then harvested and used in further experiments.

\section{Statistical analyses}

The results are presented as mean \pm S.E.M. Each value represents an average of at least 6 wells from at least three independent cultivations of each type of cells. Statistical differences among groups were determined by ANOVA. Statistical significance $*$ - $p<0.05$ was considered to be significant, ${ }^{* *} p<0.01,{ }^{* * *} \mathrm{p}$ $<0.001$. For multiple comparisons, an adjusted t-test with $\mathrm{p}$ values corrected by the Bonferroni method was used (Instat, GraphPad Software).

\section{Results}

In ovarian A2780 tumour cells and also in DLD1 colorectal carcinoma cells, melatonin decreased the cytosolic calcium concentration in a dose-dependent manner (Fig. 1A, B). The most pronounced decrease was observed at the melatonin concentration $10 \mu \mathrm{M}$ (in A2780 cells: from $4.1 \pm 0.2$ a.u. in control group vs. $3.0 \pm 0.1$ a.u. in melatonin treated group; in DLD1 cells from $4.03 \pm 0.05$ a.u. in control group vs. $2.77 \pm 0.10$ a.u. in melatonin treated group). However, melatonin did not cause any changes in cytosolic calcium in the normal

Fig. 1. Changes in levels of the cytosolic calcium in A2780 (A), DLD1 (B) and EA.hy926 (C) cells due to the melatonin treatment. In tumour cell lines A2780 and DLD1, melatonin decreased levels of cytosolic calcium in a concentrationdependent manner. In normal endothelial cell line EA.hy926, melatonin did not change levels of the cytosolic calcium. cont - untreated control, M0.1 - melatonin treatment (final concentration $0.1 \mu \mathrm{M}$ ),

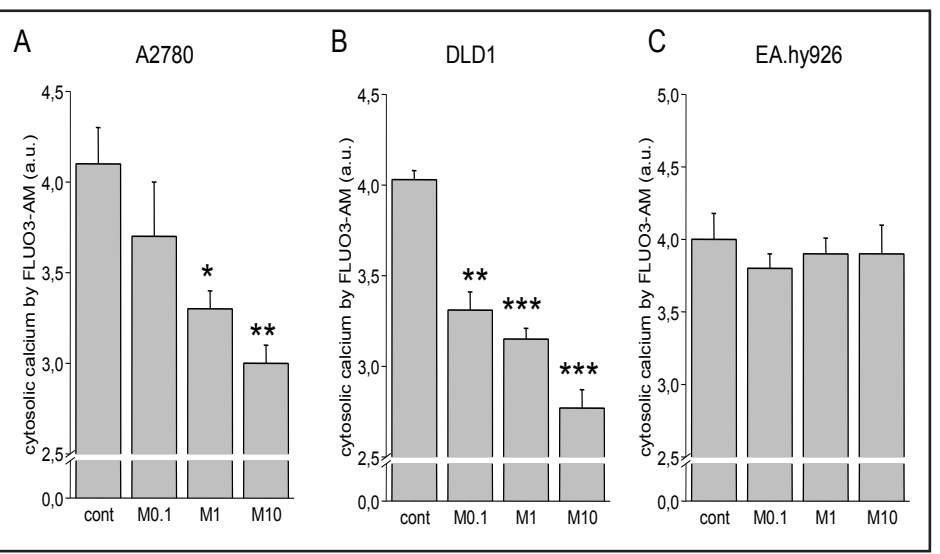
M1 - melatonin treatment (final concentration $1 \mu \mathrm{M}$ ), M10 - melatonin treatment (final concentration $10 \mu \mathrm{M}$,) for $24 \mathrm{~h}$. Results are displayed as mean \pm S.E.M. Each column represents an average of $6-9$ samples from three independent cultivations. Statistical significance ${ }^{*}$ represents $\mathrm{p}<0.05,{ }^{* *} \mathrm{p}<0.01$ and ${ }^{* * *} \mathrm{p}<0.001$. 
Fig. 2. Changes in levels of the NCX1 expression in A2780 (A, B), DLD1 (C,D) and EA.hy926 (E, F) cells due to the melatonin treatment. In tumour cell lines A2780 and DLD1, melatonin increased NCX1 mRNA (B, D) and protein (typical Western blots - A, C) by a concentrationdependent manner. In normal endothelial cell line EA.hy926, melatonin also increased NCX1 mRNA (F) and protein (E), although this increase was not so pronounced as in tumour cells. cont - untreated control, M0.1 -

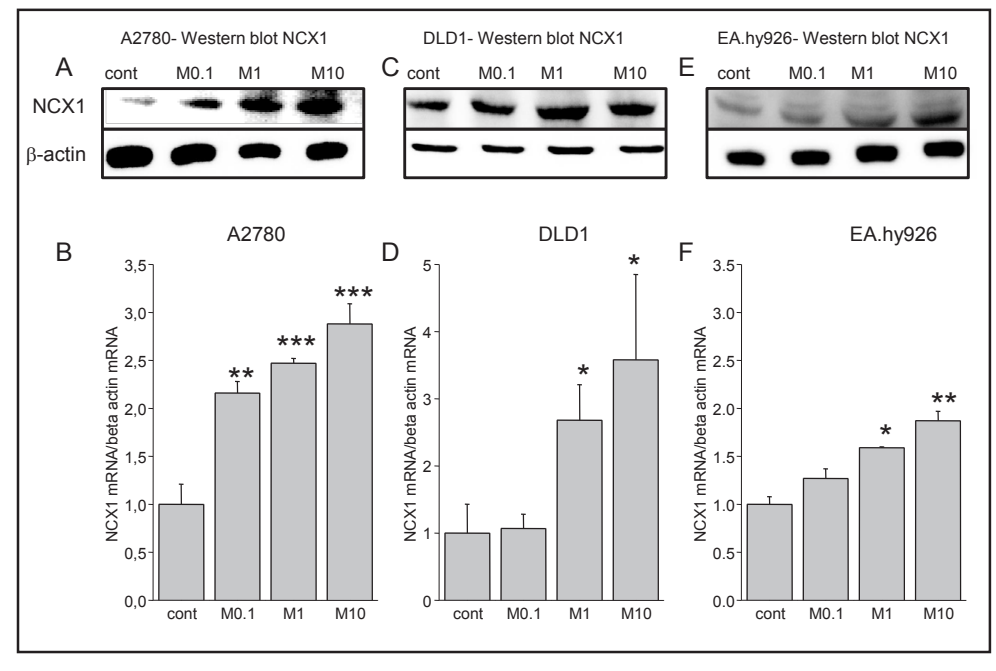
melatonin treatment (final concentration $0.1 \mu \mathrm{M}$ ), M1 - melatonin treatment (final concentration $1 \mu \mathrm{M}$ ), M10 - melatonin treatment (final concentration $10 \mu \mathrm{M}$,) for $24 \mathrm{~h}$. Results are displayed as mean \pm S.E.M. Each column represents an average of 6 -9 samples from three independent cultivations. Statistical significance * represents $\mathrm{p}<0.05,{ }^{* *} \mathrm{p}<0.01$ and ${ }^{* * *} \mathrm{p}<0.001$.

Fig. 3. Changes in levels of the $\mathrm{IP}_{3} \mathrm{R} 1$ expression in A2780 (A, B), DLD1 (C, D) and EA.hy926 (E, F) cells due to the melatonin treatment. In tumour cell lines A2780 and DLD1, melatonin increased $\mathrm{IP}_{3} \mathrm{R} 1 \mathrm{mRNA}(\mathrm{B}, \mathrm{D})$ and protein (typical Western blots - A, C) by a concentration-dependent manner. In normal endothelial cell line EA.hy926, melatonin did not cause any changes in $\mathrm{IP}_{3} \mathrm{R} 1$ mRNA

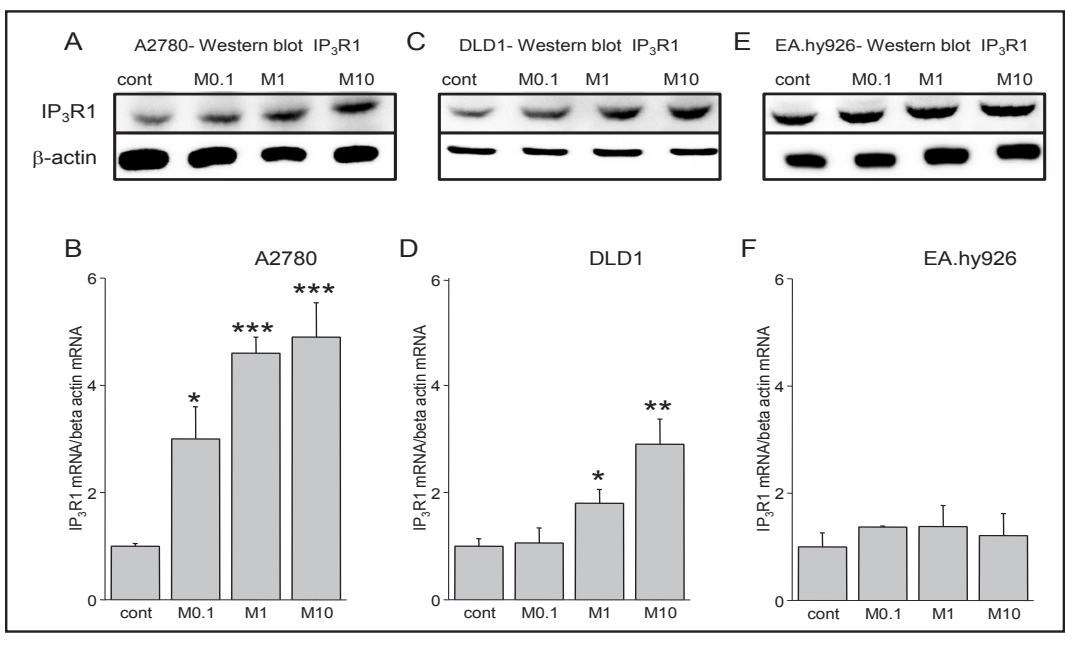
(F) and protein (E). cont - untreated control, M0.1 - melatonin treatment (final concentration $0.1 \mu \mathrm{M}$ ), M1 - melatonin treatment (final concentration $1 \mu \mathrm{M}$ ), M10 - melatonin treatment (final concentration $10 \mu \mathrm{M}$ )) for $24 \mathrm{~h}$. Results are displayed as mean \pm S.E.M. Each column represents an average of 6 -9 samples from three independent cultivations. Statistical significance ${ }^{*}$ represents $\mathrm{p}<0.05,{ }^{* *} \mathrm{p}<0.01$ and ${ }^{* * *} \mathrm{p}<0.001$.

endothelial cell line EA.hy926 (Fig. 1C). The decrease in cytosolic calcium might be due to increased expression or activity of NCX1 or PMCA, or to calcium release from the ER, presumably through $\mathrm{IP}_{3}$ receptors. Therefore, we tested the expression of NCX1 (Fig. 2). We observed melatonin-induced up-regulation of NCX1 mRNA in all three cell lines, although in A2780 and DLD1 tumour cells the increase was much greater (approximately threefold, when $10 \mu \mathrm{M}$ melatonin treatment was applied for $24 \mathrm{~h}$; Fig. 2B, D). In EA.hy926 cells, melatonin induced increase was less than two-fold when treated with $10 \mu \mathrm{M}$ melatonin (Fig. 2F). The up-regulated expression of NCX1 was verified by Western blot analysis, where the melatonin-induced increase was determined relative to $\beta$-actin in all three cell lines (Fig. 2 , 
Fig. 4. Determination of NCX1 (left) and $\mathrm{IP}_{3} \mathrm{R} 1$ (right) in EA.hy926 and DLD1 cells in response to the melatonin treatment $(10 \mu \mathrm{M})$ as determined by the fluorescence microscopy. For NCX1, primary antibody anti-rabbit NCX1 and Alexa Fluor-488 labeled secondary antibody were used. Intensity of green fluorescence indicates amount of NCX1. For IP ${ }_{3}$ 1, primary antibody anti-mouse $\mathrm{IP}_{3} \mathrm{R} 1$ and Alexa Fluor-594 labeled sec-

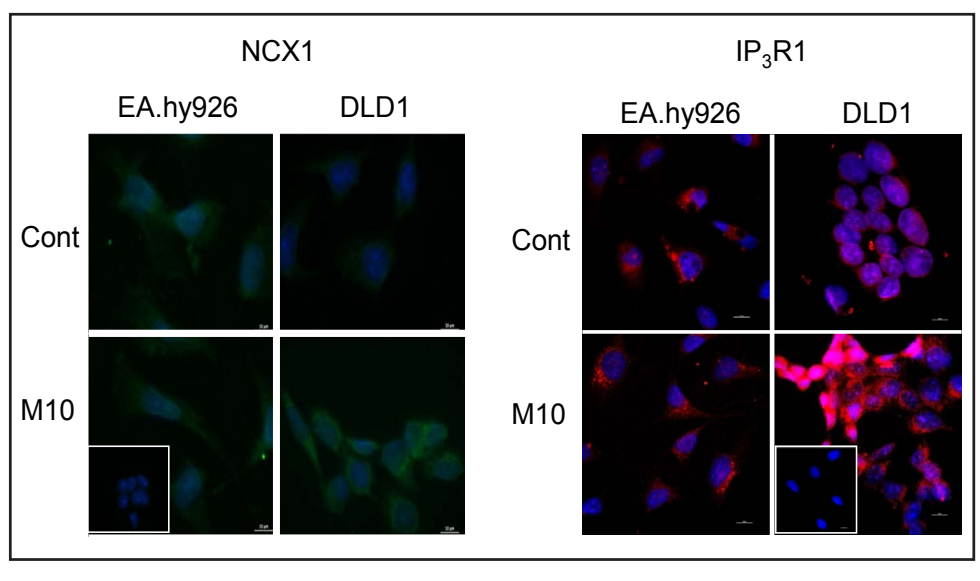
ondary antibody was used. Intensity of red fluorescence indicates amount of NCX1. cont - untreated control, M10 - melatonin treatment (final concentration $10 \mu \mathrm{M}$ ) for $24 \mathrm{~h}$, Inset represents the negative control. Bar represents $10 \mu \mathrm{m}$.

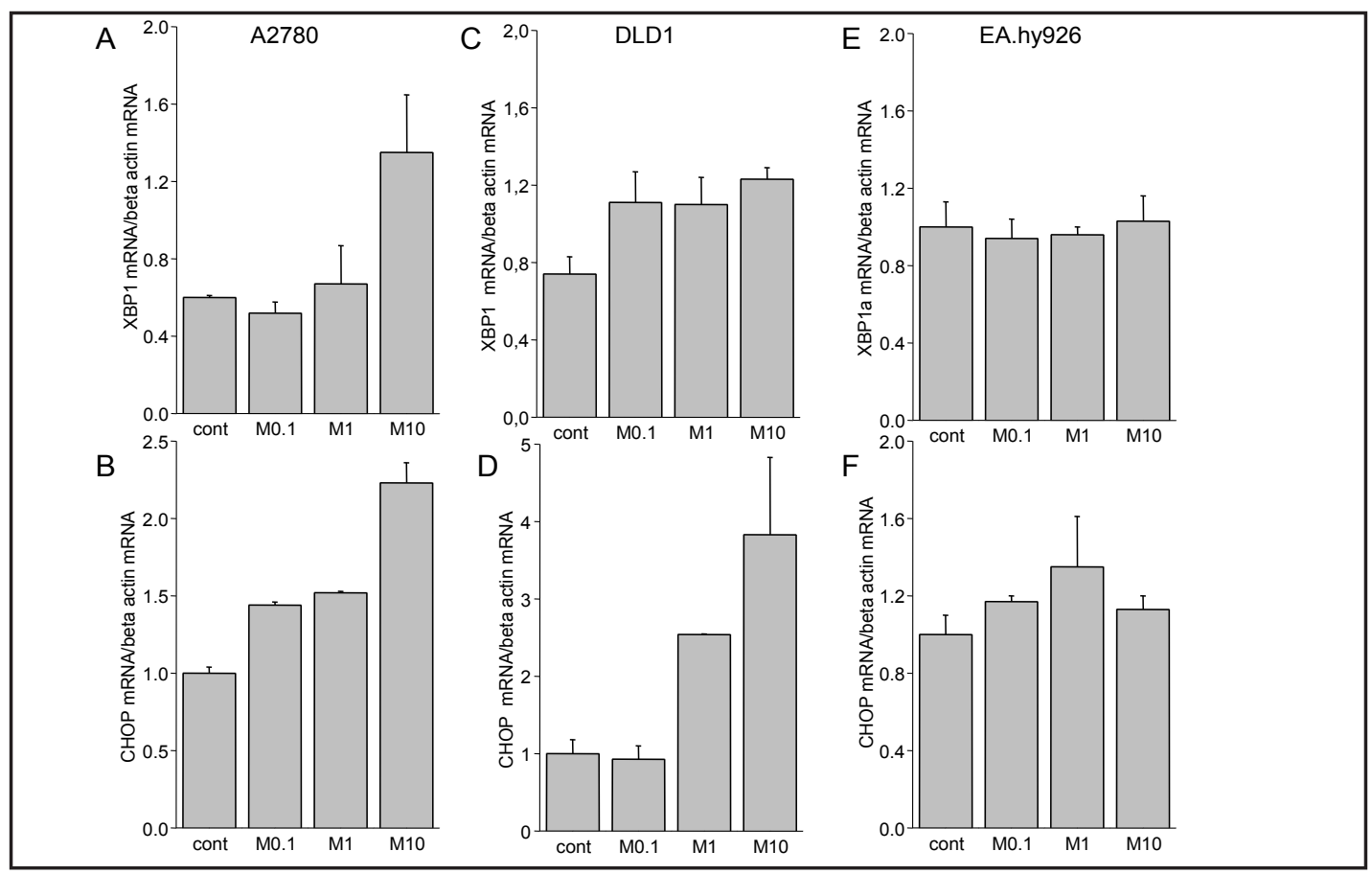

Fig. 5. Changes in levels of the ER stress markers in A2780 (A,B), DLD1 (C,D) and EA.hy926 (E,F) cells in response to the melatonin treatment. In tumour cell lines A2780 and DLD1, melatonin increased CHOP and XBP1 mRNA by a concentration-dependent manner. In normal endothelial cell line EA.hy926, melatonin did not cause any changes in mRNA of ER stress markers (XBP1 and CHOP). cont - untreated control, M0.1 - melatonin treatment (final concentration $0.1 \mu \mathrm{M}$ ), M1 - melatonin treatment (final concentration $1 \mu \mathrm{M}$ ), M10 - melatonin treatment (final concentration $10 \mu \mathrm{M}$ ) for $24 \mathrm{~h}$. Results are displayed as mean \pm S.E.M. Each column represents an average of $6-9$ samples from three independent cultivations. Statistical significance * represents $\mathrm{p}<0.05$, $^{* *} \mathrm{p}<0.01$ and ${ }^{* * *} \mathrm{p}<0.001$.

A, C, E); and also by immunofluorescence in the EA.hy926 and DLD1 cell lines (Fig. 4, left). In addition, we measured plasma membrane $\mathrm{Ca}^{2+}$ ATPase (PMCA) gene expression and did not observe any changes due to melatonin treatment (not shown). Nevertheless, we observed a significant increase in type $1 \mathrm{IP}_{3} \mathrm{Rs}$ in the melatonin-treated A2780 and DLD1 tumour cell 
Fig. 6. Changes in the ER stress in A2780, DLD1 and EA.hy926 cells in response to the melatonin treatment, as determined by the fluorescent microscopy by thioflavin (green). Nuclei of the cells are stained by DAPI (blue). cont - untreated control, M10 melatonin treatment (final concentration $10 \mu \mathrm{M}$ ) for $24 \mathrm{~h}, \mathrm{NC}$ negative control. Bar represents $50 \mu \mathrm{m}$.
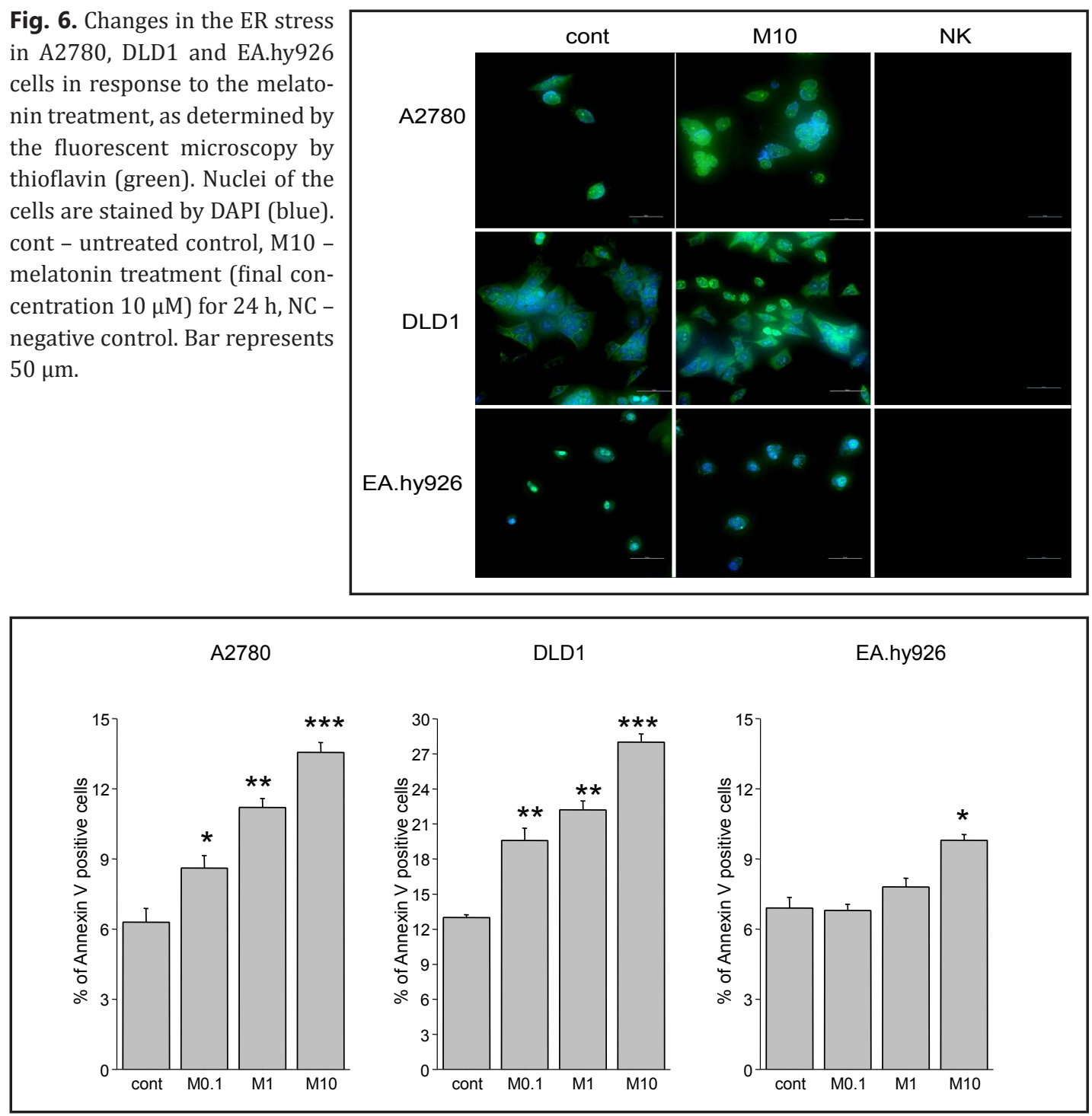

Fig. 7. Melatonin treatment increases apoptosis in A2780, DLD1, but very weakly in EA.hy926 cells, as determined by Annexin V-Fluos. In tumour cell lines A2780 and DLD1, melatonin increased apoptosis approximately twice, but in normal endothelial cell line EA.hy926 only 1.3-times. cont - untreated control, M0.1 - melatonin treatment (final concentration $0.1 \mu \mathrm{M}$ ), M1 - melatonin treatment (final concentration 1 $\mu \mathrm{M}$ ), M10 - melatonin treatment (final concentration $10 \mu \mathrm{M}$,) for $24 \mathrm{~h}$. Results are displayed as mean \pm S.E.M. Each column represents an average of 6 -9 samples from three independent cultivations. Statistical significance $^{*}$ represents $\mathrm{p}<0.05,{ }^{* *} \mathrm{p}<0.01$ and ${ }^{* * *} \mathrm{p}<0.001$.

lines (Fig. 3A, B, C, D), but not in EA.hy926 endothelial cells (Fig. 3 E, F) that was determined on both, mRNA (Fig. 3, B, D, F) and protein (Fig. 3, A, C, E) level. Immunofluorescence assays using $\mathrm{IP}_{3} \mathrm{R} 1$ antibody did not show any differences in the IP ${ }_{3} \mathrm{R} 1$ signal (red) in EA.hy926 cells after melatonin treatment, but a rapid increase in the $\mathrm{IP}_{3} \mathrm{R} 1$ signal was observed in melatonin treated DLD1 cells (Fig. 4, right). Since it is known that depletion of calcium from the ER (also through $\mathrm{IP}_{3} \mathrm{Rs}$ ) causes ER stress, we measured markers of ER stress - CHOP (Fig.5 B, D, F) and XBP1(Fig.5 A, C, E) in all three types of cells. ER stress (determined by increased expression of CHOP and XBP1) was evident in A2780 and DLD1 cells (especially, at melatonin concentration $10 \mu \mathrm{M}$ ), but not in EA.hy926 cells (Fig. $5 \mathrm{E}, \mathrm{F}$ ), where no changes in the expression of CHOP and XBP1 were determined in control and melatonin treated

\section{KARGER}


Fig. 8. Involvement of the NCX1 and $\mathrm{IP}_{3} \mathrm{R} 1$ in the melatonin-induced apoptosis in A2780 and DLD1 cells. Group of A2780/DLD1 cells was silenced by either NCX1 or $\mathrm{IP}_{3} \mathrm{R} 1$ and subsequently treated with $10 \mu \mathrm{M}$ melatonin for $24 \mathrm{~h}$. Afterwards, apoptosis was determined by Annexin V-Fluos. cont - untreated control, M10 melatonin treatment, siNCX - cells

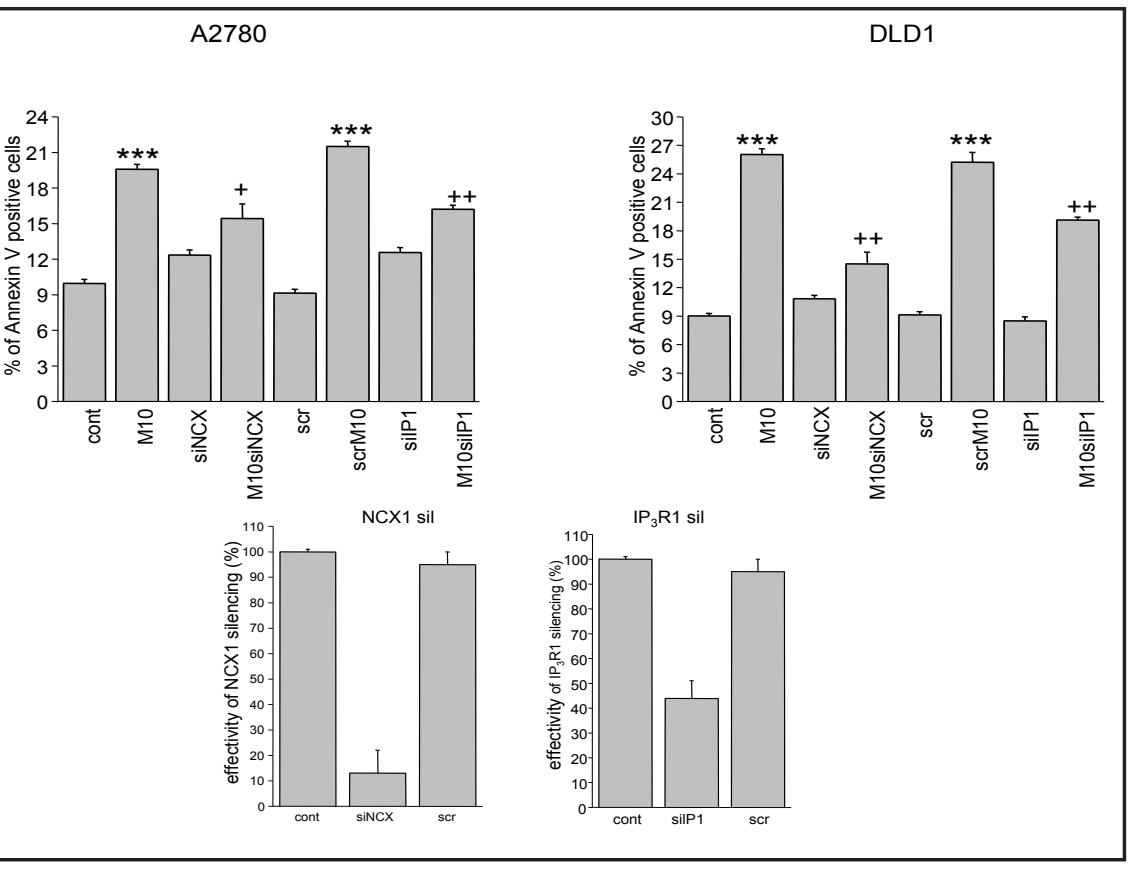
silenced with NCX1 siRNAs, M10siNCX - cells silenced with NCX1 siRNAs and treated with melatonin, scr - cells silenced with ON-TARGETplus Non-targeting Control Pool (negative control siRNAs), scrM10 - cells silenced with ON-TARGETplus Nontargeting Control Pool and treated with melatonin, silP1 - cells silenced with IP ${ }_{3}$ R1 siRNAs, M10silP1 - cells silenced with $\mathrm{IP}_{3} \mathrm{R} 1$ siRNAs and treated with melatonin. Results are displayed as mean \pm S.E.M. Each column represents an average of 3-6 samples. Statistical significance compared to control $-* * * \mathrm{p}<0.001$ and compared to melatonin-treated group + represents $\mathrm{p}<0.05$ and $++\mathrm{p}<0.01$.

cells. Melatonin-induced ER stress in A2780 and DLD1 cells was verified by fluorescence microscopy using Thioflavin T (Fig. 6, green signal). Cell nuclei are stained in blue with DAPI (Fig. 6, blue signal). ER stress is often connected with apoptosis induction. Therefore, we measured apoptosis in A2780, DLD1 and EA.hy926 cells after the melatonin treatment (Fig. 7). The increase in apoptosis after melatonin treatment (10 $\mu \mathrm{M}$ for $24 \mathrm{~h})$ in DLD1 and A2780 cells was more than two-fold, while in EA.hy926, apoptosis was only elevated 1.4-fold. To determine if the melatonin induced changes in the expression of NCX1 and IP R1 in A2780 and DLD1 cells might affect apoptosis induction, we silenced genes for these two proteins and measured apoptosis in all types of cells after melatonin treatment (Fig. 8). In DLD1 cells, knockdown with NCX1 siRNA decreased melatonin-induced apoptosis from $25.24 \pm 1.04 \%$ to $14.51 \pm 1.23 \%$ and also $\mathrm{IP}_{3} \mathrm{R} 1$ siRNA partially prevented melatonin-induced apoptosis (to $19.13 \pm 0.33 \%$ ) compared with non-siRNA cells treated with melatonin. Similarly in A2780 cells, lower level of melatonin-induced apoptosis was observed in groups, in which NCX1 (from $21.50 \pm 0.46 \%$ to $15.44 \pm 1.23 \%$ ) or $I_{3} \mathrm{R} 1$ (to $16.22 \pm 0.43 \%$ ) was silenced compared with non-siRNA cells treated with melatonin. Since apoptosis in melatonin-treated cells knockdown with NCX1 and IP R1 siRNA was higher than in control, untreated groups $(9.03 \pm 0.27 \%$ in DLD1 cells and $9.95 \pm 0.35 \%$ in A2780 cells), it becomes clear that these two calcium transport systems contribute only partially to the mechanism of melatonin-induced apoptosis. The efficiency of the NCX1 silencing was approximately 80-90\%, while that of silP ${ }_{3} \mathrm{R} 1$ silencing was only $50-60 \%$. The antioxidant effects of melatonin were determined by total ROS detection (Fig. 9). While in normal EA.hy926 cells total ROS content decreased on melatonin treatment in a concentration-dependent manner (from $14.8 \pm 0.2 \mathrm{RFU} / \mu \mathrm{g}$ protein in control group to $4.7 \pm 0.2 \mathrm{RFU} / \mu \mathrm{g}$ protein in group treated with $10 \mu \mathrm{M}$ melatonin), ROS decrease in A2780 and DLD1 tumour cells was much lower (from 25.3 $\pm 0.2 \mathrm{RFU} / \mu \mathrm{g}$ protein 


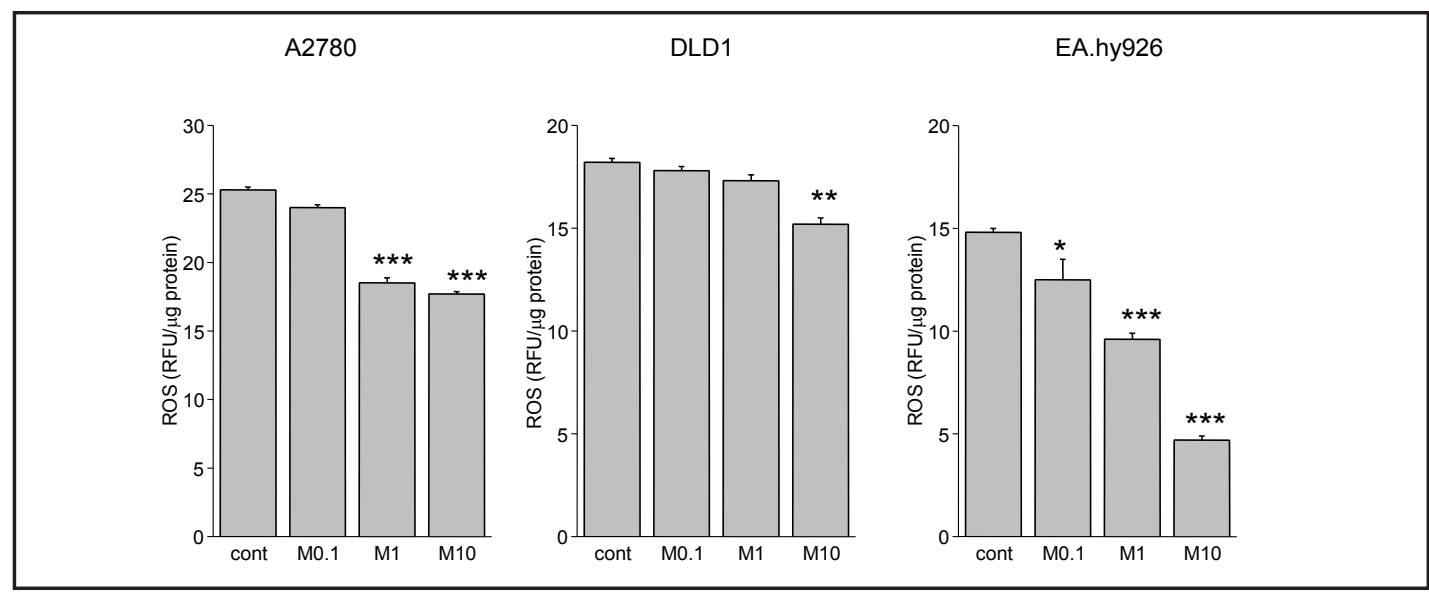

Fig. 9. Determination of ROS decreases in tumour A2780 and DLD1 cells and normal epithelial EA.hy926 cells due to the melatonin treatment. In EA.hy926 cells, melatonin presents its antioxidant effect through a decrease of ROS in a concentration-dependent manner. Antioxidant effect of melatonin was much smaller in tumour cell lines A2780 and DLD1. cont - untreated control, M0.1 - melatonin treatment (final concentration $0.1 \mu \mathrm{M}$ ), M1 - melatonin treatment (final concentration $1 \mu \mathrm{M}$ ), M10 - melatonin treatment (final concentration $10 \mu \mathrm{M}$,) for $24 \mathrm{~h}$. Results are displayed as mean \pm S.E.M. Each column represents an average of 3 -6 samples from two independent cultivations. Statistical significance * represents $\mathrm{p}<0.05,{ }^{* *} \mathrm{p}<0.01$ and $* * * \mathrm{p}<0.001$.

Fig. 10. Determination of ROS in A2780, DLD1 and EA.hy926 cells in response to the melatonin treatment as determined by the fluorescent microscopy using CellROX Green reagent. Intensity of green fluorescence indicates amount of ROS. cont - untreated control, M10 - melatonin treatment (final concentration $10 \mu \mathrm{M}$ ) for $24 \mathrm{~h}, \mathrm{NC}$ - negative control. Bar represents $50 \mu \mathrm{m}$.

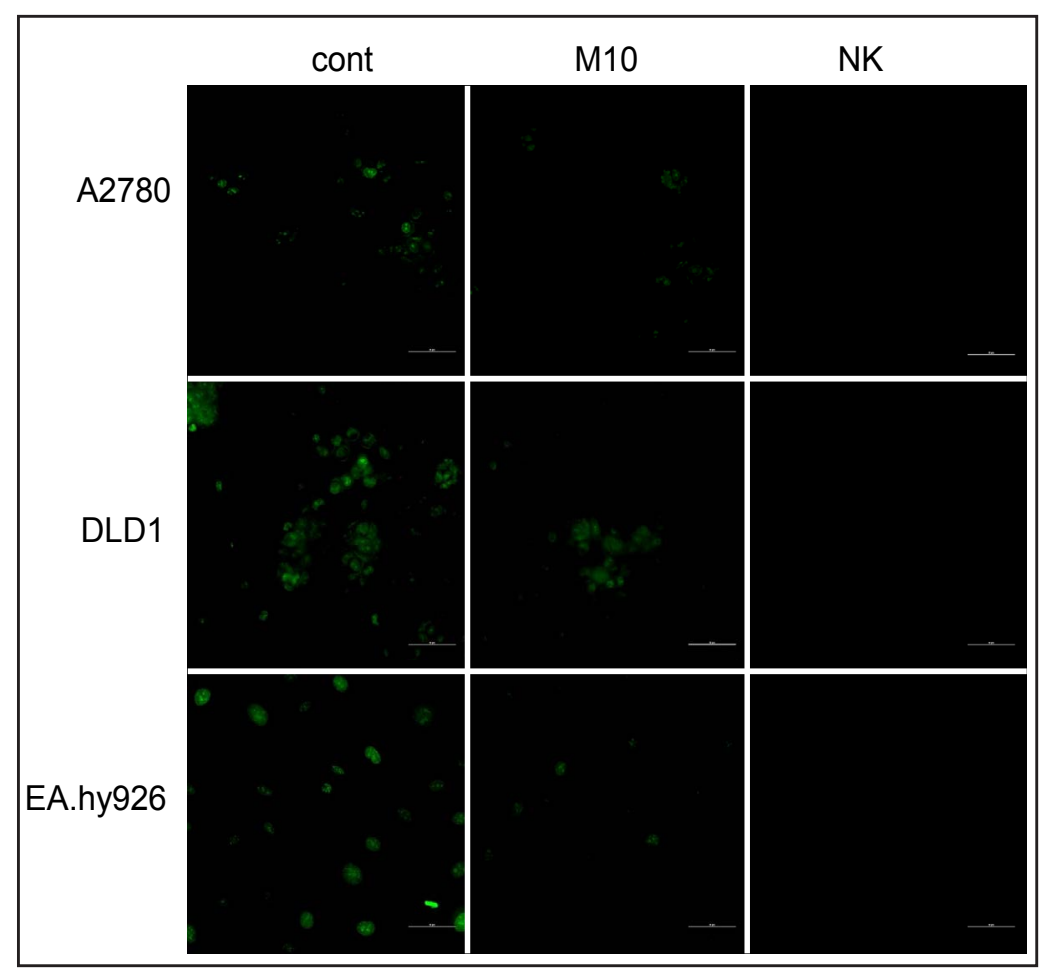

in control group to $17.7 \pm 0.17 \mathrm{RFU} / \mu \mathrm{g}$ protein in group treated with $10 \mu \mathrm{M}$ melatonin in A2780 cells and from $18.2 \pm 0.2 \mathrm{RFU} / \mu \mathrm{g}$ protein to $15.2 \pm 0.3 \mathrm{RFU} / \mu \mathrm{g}$ protein in DLD1 cells). These results were verified by fluorescent microscopy using CellROX Green reagent (Fig. 10), where the fluorescent signal after melatonin treatment was much lower in EA.hy926 than in A2780 and DLD1 cells. 


\section{Discussion}

In this study, we have shown that melatonin acts differently on A2780 (derived from ovarian cancer) and DLD1 (derived from colorectal carcinoma) tumour cells, compared with cells of the normal endothelial EA.hy926 cell line. In tumour cell lines, melatonin was able to decrease levels of cytosolic calcium primarily through increased expression of NCX1, generate ER stress, and induce apoptosis via calcium release from the ER as a consequence of increased expression of $\mathrm{IP}_{3} \mathrm{R} 1$. However, in normal EA.hy 926 cells, melatonin acts mainly as an antioxidant agent, thus decreasing the amount of total ROS.

ROS species produced by oxidative stress have been detected in various cancers due to their high metabolic activity, and these ROS may promote many processes that maintain an aggressive phenotype [41]. Anti-oxidant compounds are generally considered as a protective factor against cancer [42]. Melatonin is well known as a potent scavenger of ROS such as hydroxyl radicals, peroxyl radicals, superoxide anion radicals and hydrogen peroxide [4347]. In our experiments we detected higher levels of ROS in tumour cells (A2780 - 25.3 \pm 0.2 RFU/ $\mu$ g prot., DLD1 - 18.2 $\pm 0.2 \mathrm{RFU} / \mu \mathrm{g}$ prot.) compared with non-tumour endothelial EA.hy926 cells ( $14.8 \pm 0.2 \mathrm{RFU} / \mu \mathrm{g}$ prot.). Nevertheless, a melatonin induced decrease in ROS was robust in non-cancer EA.hy926 cells (app. 68\% at $10 \mu \mathrm{M}$ melatonin compared with the untreated control), but relatively weak in both types of cancer cells (approximately $30 \%$ in A2780 around $16.5 \%$ in DLD1 with $10 \mu \mathrm{M}$ melatonin treatment compared with untreated controls), indicating that melatonin acts differently in tumour cells compared with normal cells. This difference is interesting both from the theoretical and therapeutic points of view, but the mechanisms behind it are not understood. In normal cells, the products of several tumour suppressor genes counteract oxidative stress and maintain the redox balance by prevention of lipid peroxidation and oxidative damage to DNA and proteins [48]. In the absence of wild-type tumour suppressor genes, such as TP53, cancer cells switch off several antioxidative pathways, leading to ROS accumulation [49].

In stark contrast to ROS, $\mathrm{Ca}^{2+}$ exists in only one biologically relevant form that undergoes neither catabolic degradation nor anabolic synthesis (for a review, see Görlach et al. [50]). Interactions between ROS and calcium signalling can be considered as bidirectional, wherein ROS can regulate cellular calcium signalling, while calcium signalling is essential for ROS production [51]. Thus, in addition to calcium regulation of ROS generation, redox state and ROS have been shown to modulate the activity of a variety of $\mathrm{Ca}^{2+}$ channels, pumps, and exchangers [50]. In our study, melatonin decreased cytosolic calcium in a concentration dependent manner in DLD1 and A2780 tumour cells. However, such a melatonin-induced decrease in cytosolic calcium was not observed in endothelial EA.Hy926 cells. A similar melatonin-induced decrease in cytosolic calcium has already been described in mouse pancreatic acinar cells [28] and human neuroblastoma SH-SY5Y cells [8]. The effect of melatonin could be explained on the basis of stimulated $\mathrm{Ca}^{2+}$ transport out of the cell through the plasma membrane and by stimulation of $\mathrm{Ca}^{2+}$ reuptake into the ER. Generally, two major extrusion systems are responsible for the calcium extrusion from the cell - plasma membrane ATPase (PMCA) and NCX. We have shown that melatonin significantly increased the expression of NCX1 (major form of NCX), but did not change the expression of PMCA (not shown). Melatonin-induced up-regulation of NCX1 has not previously been described in cancer cells. Nevertheless, it was described in the prevention of pancreatic damage [52], since melatonin was able to reduce pancreatic damage via the up-regulation of NCX expression, which can alleviate calcium overload in pancreatic acinar cells. Taken together, melatonin might exert protective effects against cytosolic calcium overload.

Besides NCX, some other transporters have been shown to be affected by melatonin. Celik and Naziroglu [53] observed a modulatory role of intracellular and extracellular melatonin on $\mathrm{Ca}^{2+}$ influx and apoptosis through a transient receptor potential melastatin like 2 (TRPM2) channel in transfected Chinese hamster ovary (CHO) cells. Also, melatonin activates phospholipase $\mathrm{C}$ to generate $\mathrm{IP}_{3}$ and open ER-localised $\mathrm{IP}_{3}$-sensitive $\mathrm{Ca}^{2+}$ channels in the malaria parasite Plasmodium falciparum [54]. We have shown a robust up-regulation 
in the expression of $\mathrm{IP}_{3} \mathrm{R} 1$ in A2780 and DLD1 tumour cells, but not in epithelial EA.hy926 cells. Expression of other types of $\mathrm{IP}_{3} \mathrm{Rs}-\mathrm{IP}_{3} \mathrm{R} 2$ and $\mathrm{IP}_{3} \mathrm{R} 3$ - was not changed (not shown). Release of calcium through $\mathrm{IP}_{3} \mathrm{R} 1$ is tightly associated with the induction of apoptosis via the inner, mitochondrial pathway [55]. Therefore, we studied the effect of melatonin on potential apoptosis induction in two different tumour cell lines - A2780 and DLD1. To compare the effect of melatonin on non-tumour cells, we used endothelial EA.hy926 cells. Melatonin-induced apoptosis was much more pronounced in A2780 and DLD1 tumour cells than in endothelial EA.hy.926 cells. The ability of melatonin to induce apoptosis has already been described in cancer cells, e.g. hepatoma cells [24], but also, to a limited extent, in nontumour cells.

Moreover, melatonin promotes the apoptosis induced by other compounds, e.g. sorafenib in hepatocellular carcinoma [56], cisplatin in hepatocellular carcinoma [57], fluorouracil in oesophageal squamous cell carcinoma [58], etc. Although diverse mechanisms for melatonininduced apoptosis have been suggested, many of them have the same denominator - ER stress. Activation of the mitochondrial pathway of apoptosis is deeply dependent on calcium release from the ER due to ER stress [55, 59]. We have shown that in tumour cells, melatonin is able to induce ER stress and activate the apoptotic process. This observation was already made in rats with diethylnitrosamine-induced hepatocarcinogenesis [20]. However, ER stress markers were not elevated in non-tumour EA.hy 926 cells. The protective effects of melatonin against ER stress have already been described in some non-tumour cell lines. The protective effect of melatonin against ER stress induced by kainic acid in neurons was described by Xue et al. [60]. This effect might be associated with the modulation of intracellular $\mathrm{Ca}^{2+}$ levels and cellular homeostasis. Accumulating evidence emphasises the contribution of melatonin towards the maintenance of ER and mitochondrial homeostasis, which makes melatonin a promising pharmacological agent against neurodegenerative diseases [5, 61].

Multiple mechanisms underlying melatonin's ability to counteract tumour growth have been described up to now. These include, but are not limited to, it's various antioxidant effects, modulation of the cell cycle, induction of apoptosis, inhibition of telomerase activity, ability to antagonise metastasis, prevention of circadian disruption, anti-angiogenesis, epigenetic effects, inhibition of growth factor uptake, stimulation of cell differentiation, and activation of the immune system $[62,63]$. Based on our results we can conclude that melatonin acts differently in tumour cells than in normal endothelial cells, probably due to reorganisation of signalling pathways in tumour cells. Besides the known effects of melatonin as an ROS scavenger, its modulation of intracellular calcium might significantly participate in deciding the fate of tumour cells and inducing apoptosis. Different targeting of calcium transport systems might explain some mechanisms whereby melatonin can exert its anticancer effects and therefore represent potential novel therapeutic compound for cancer treatment. Thus, a potential therapeutic or clinical relevance of drugs that affect the level of cytosolic calcium in combination with melatonin should be further studied.

\section{Acknowledgements}

This work was supported by grants VEGA 2/0073/16, VEGA 2/0082/16 and APVV 140318.

\section{Disclosure Statement}

The authors declare no conflict of interest regarding the publication of this paper. 


\section{Cellular Physiology Cell Physiol Biochem 2017;44:763-777 \begin{tabular}{l|l|l} 
and Biochem 10.1159/000485290 & $\begin{array}{l}\text { C } 2017 \text { The Author(s). Published by S. Karger AG, Basel } \\
\text { www.karger.com/cpb }\end{array}$ \\
\hline
\end{tabular}}

Chovancova et al.: Melatonin and Cancer

\section{References}

1 Tosches MA, Bucher D, Vopalensky P, Arendt D: Melatonin signaling controls circadian swimming behavior in marine zooplankton. Cell 2014;159:46-57.

-2 Gandhi AV, Mosser EA, Oikonomou G, Prober DA: Melatonin is required for the circadian regulation of sleep. Neuron 2015;85:1193-1199.

-3 Tan DX, Manchester LC, Terron MP, Flores LJ, Reiter RJ: One molecule, many derivatives: A never-ending interaction of melatonin with reactive oxygen and nitrogen species? J Pineal Res 2007;42:28-42.

4 Zhang HM, Zhang Y: Melatonin: A well-documented antioxidant with conditional pro-oxidant actions. J Pineal Res 2014;57:131-146.

5 Hu W, Ma Z, Di S, Jiang S, Li Y, Fan C, Yang Y, Wang D: Snapshot: implications for melatonin in endoplasmic reticulum homeostasis. Br J Pharmacol 2016;173:3431-3442.

-6 Hardeland R: Antioxidative protection by melatonin: Multiplicity of mechanisms from radical detoxification to radical avoidance. Endocrine 2005;27:119-130.

7 Hong Y, Won J, Lee Y, Lee S, Park K, Chang KT, Hong Y: Melatonin treatment induces interplay of apoptosis, autophagy, and senescence in human colorectal cancer cells. J Pineal Res 2014;56:264-274.

8 Suwanjang W, Abramov AY, Charngkaew K, Govitrapong P, Chetsawang B: Melatonin prevents cytosolic calcium overload, mitochondrial damage and cell death due to toxically high doses of dexamethasoneinduced oxidative stress in human neuroblastoma SH-SY5Y cells. Neurochem Int 2016;97:34-41.

-9 Carbajo-Pescador S, García-Palomo A, Martín-Renedo J, Piva M, González-Gallego J, Mauriz JL: Melatonin modulation of intracellular signaling pathways in hepatocarcinoma HepG2 cell line: Role of the MT1 receptor. J Pineal Res 2011;51:463-471.

10 Plaimee P, Weerapreeyakul N, Barusrux S, Johns NP: Melatonin potentiates cisplatin-induced apoptosis and cell cycle arrest in human lung adenocarcinoma cells. Cell Prolif 2015;48:67-77.

11 Fan C, Pan Y, Yang Y, Di S, Jiang S, Ma Z, Li T, Zhang Z, Li W, Li X, Reiter RJ, Yan X: HDAC1 inhibition by melatonin leads to suppression of lung adenocarcinoma cells via induction of oxidative stress and activation of apoptotic pathways. J Pineal Res 2015;59:321-333.

12 Ma Z, Yang Y, Fan C, Han J, Wang D, Di S, Hu W, Liu D, Li X, Reiter RJ, Yan X: Melatonin as a potential anticarcinogen for non-small-cell lung cancer. Oncotarget 2016;7:46768-46784.

13 Mao L, Summers W, Xiang S, Yuan L, Dauchy RT, Reynolds A, Wren-Dail MA, Pointer D, Frasch T, Blask DE, Hill SM: Melatonin represses metastasis in Her2-postive human breast cancer cells by suppressing RSK2 expression. Mol Cancer Res 2016;14:1159-1169.

14 Paroni R, Terraneo L, Bonomini F, Finati E, Virgili E, Bianciardi P, Favero G, Fraschini F, Reiter RJ, Rezzani R, Samaja M: Antitumour activity of melatonin in a mouse model of human prostate cancer: Relationship with hypoxia signalling. J Pineal Res 2014;57:43-52.

15 Joo SS, Yoo YM: Melatonin induces apoptotic death in LNCaP cells via p38 and JNK pathways: Therapeutic implications for prostate cancer. J Pineal Res 2009;47:8-14.

16 Quintana C, Cabrera J, Perdomo J, Estévez F, Loro JF, Reiter RJ, Quintana J: Melatonin enhances hyperthermia-induced apoptotic cell death in human leukemia cells. J Pineal Res 2016:381-395.

17 Zhelev Z, Ivanova D, Bakalova R, Aoki I, Higashi T: Synergistic cytotoxicity of melatonin and new-generation anticancer drugs against leukemia lymphocytes but not normal lymphocytes. Anticancer Res 2017;37:149159.

18 Li W, Fan M, Chen Y, Zhao Q Song C, Yan Y, Jin Y, Huang Z, Lin C, Wu J: Melatonin induces cell apoptosis in AGS cells through the activation of JNK and P38 MAPK and the suppression of nuclear Factor-Kappa B: A novel therapeutic implication for gastric cancer. Cell Physiol Biochem 2015;37:2323-2338.

19 Liu L, Xu Y, Reiter RJ, Pan Y, Chen D, Liu Y, Pu X, Jiang L, Li Z: Inhibition of ERK1/2 Signaling Pathway is Involved in Melatonin's Antiproliferative Effect on Human MG-63 Osteosarcoma Cells. Cell Physiol Biochem 2016;39:2297-2307.

20 Moreira AJ, Ordoñez R, Cerski CT, Picada JN, García-Palomo A, Marroni NP, Mauriz JL, González-Gallego J: Melatonin Activates Endoplasmic Reticulum Stress and Apoptosis in Rats with Diethylnitrosamine-Induced Hepatocarcinogenesis. PLoS One 2015;10:e0144517.

-21 Muchowicz A, Firczuk M, Wachowska M, Kujawa M, Jankowska-Steifer E, Gabrysiak M, Pilch Z, Kłossowski S, Ostaszewski R, Golab J: SK053 triggers tumor cells apoptosis by oxidative stress-mediated endoplasmic reticulum stress. Biochem Pharmacol 2015;93:418-427. 


\section{Cellular Physiology Cell Physiol Biochem 2017;44:763-777 \begin{tabular}{ll|l} 
and Biochemistry Published onIIne: November 23, 2017 & $\begin{array}{l}\text { C) } 2017 \text { The Author(s). Published by S. Karger AG, Basel } \\
\text { www.karger.com/cpb }\end{array}$ \\
\hline
\end{tabular}}

Chovancova et al.: Melatonin and Cancer

22 Fulda S: Tumor resistance to apoptosis. Int J Cancer 2009;124:511-515.

-23 Ordoñez R, Carbajo-Pescador S, Prieto-Dominguez N, García-Palomo A, González-Gallego J, Mauriz JL: Inhibition of matrix metalloproteinase- 9 and nuclear factor kappa B contribute to melatonin prevention of motility and invasiveness in HepG2 liver cancer cells. J Pineal Res 2014;56:20-30.

-24 Bu LJ, Yu HQ Fan LL, Li XQ, Wang F, Liu JT, Zhong F, Zhang CJ, Wei W, Wang H, Sun GP: Melatonin, a novel selective ATF-6 inhibitor, induces human hepatoma cell apoptosis through COX-2 downregulation. World J Gastroenterol 2017;23:986-998.

25 Zha L, Fan L, Sun G, Wang H, Ma T, Zhong F, Wei W: Melatonin sensitizes human hepatoma cells to endoplasmic reticulum stress-induced apoptosis. J Pineal Res 2012;52:322-331.

26 Yeh CM, Lin CW, Yang JS, Yang WE, Su SC, Yang SF: Melatonin inhibits TPA-induced oral cancer cell migration by suppressing matrix metalloproteinase- 9 activation through the histone acetylation. Oncotarget 2016;7:21952-21967.

27 Del Castillo-Vaquero A, Salido GM, Gonzalez A: Melatonin induces calcium release from CCK-8- and thapsigargin-sensitive cytosolic stores in pancreatic AR42J cells. J Pineal Res 2010;49:256-263.

28 Santofimia-Castaño P, Ruy DC, Fernandez-Bermejo M, Salido GM, Gonzalez A: Pharmacological dose of melatonin reduces cytosolic calcium load in response to cholecystokinin in mouse pancreatic acinar cells. Mol Cell Biochem 2014;397:75-86.

-29 Hudecova S, Lencesova L, Csaderova L, Sedlak J, Bohacova V, Laukova M, Krizanova O: Isoproterenol accelerates apoptosis through the over-expression of the sodium/calcium exchanger in HeLa cells. Gen Physiol Biophys 2013;32:311-323.

-30 Markova J, Hudecova S, Soltysova A, Sirova M, Csaderova L, Lencesova L, Ondrias K, Krizanova O: Sodium/ calcium exchanger is upregulated by sulfide signaling, forms complex with the $\beta_{1}$ and $\beta_{3}$ but not $\beta_{2}$ adrenergic receptors, and induces apoptosis. Pflug Arch Eur J Physiol 2014;466:1329-1342.

-31 Lencesova L, Krizanova O: IP 3 receptors, stress and apoptosis. Gen Physiol Biophys 2012;31:119-130.

-32 Franco-Salla GB, Prates J, Cardin LT, dos Santos ARD, Silva WA, da Cunha BR, Tajara EH, Oliani SM, Rodrigues-Lisoni FC: Euphorbia tirucalli modulates gene expression in larynx squamous cell carcinoma. BMC Complement Altern Med 2016;16:136.

-33 Futatsugi A, Kuwajima G, Mikoshiba K: Muscle-specific mRNA isoform encodes a protein composed mainly of the N-terminal 175 residues of type 2 Ins(1, 4,5) $\mathrm{P}_{3}$ receptor. Biochem J 1998;334:559-563.

-34 Sundivakkam PC, Kwiatek AM, Sharma TT, Minshall RD, Malik AB, Tiruppathi C: Caveolin-1 scaffold domain interacts with TRPC1 and IP 3 R3 to regulate $\mathrm{Ca}^{2+}$ store release-induced $\mathrm{Ca}^{2+}$ entry in endothelial cells. Am J Physiol Cell Physiol 2009;296:C403-C413.

-35 Kudo T, Kanemoto S, Hara H, Morimoto N, Morihara T, Kimura R, Tabira T, Imaizumi K, Takeda M: A molecular chaperone inducer protects neurons from ER stress. Cell Death Differ 2008;15:364-375.

-36 Savic S, Ouboussad L, Dickie LJ, Geiler J, Wong C, Doody GM, Churchman SM, Ponchel F, Emery P, Cook GP, Buch MH, Tooze RM, McDermott MF: TLR dependent XBP-1 activation induces an autocrine loop in rheumatoid arthritis synoviocytes. J Autoimmun 2014;50:59-66.

-37 Lowry OH, Rosebrough NJ, Farr AL, Randall RJ: Protein measurement with the Folin phenol reagent. J Biol Chem 1951;193:265-275.

-38 Lencesova L, Hudecova S, Csaderova L, Markova J, Soltysova A, Pastorek M, Sedlak J, Wood ME, Whiteman M, Ondrias K, Krizanova O: Sulphide signalling potentiates apoptosis through the up-regulation of $\mathrm{IP}_{3}$ receptor types 1 and 2 Acta Physiol 2013;208:350-361.

-39 Beriault DR, Werstuck GH: Detection and quantification of endoplasmic reticulum stress in living cells using the fluorescent compound, Thioflavin T. Biochim Biophys Acta Mol Cell Res 2013;1833:2293-2301.

40 Hudecova S, Lencesova L, Csaderova L, Sirova M, Cholujova D, Cagala M, Kopacek J, Dobrota D, Pastorekova S, Krizanova O: Chemically mimicked hypoxia modulates gene expression and protein levels of the sodium calcium exchanger in HEK 293 cell line via HIF-1 $\alpha$. Gen Physiol Biophys 2011;30:196-206.

41 Sosa V, Moliné T, Somoza R, Paciucci R, Kondoh H, Lleonart ME: Oxidative stress and cancer: An overview. Ageing Res Rev 2013;12:376-390.

42 Martinez-Useros J, Li W, Cabeza-Morales M, Garcia-Foncillas J: Oxidative Stress: A New Target for Pancreatic Cancer Prognosis and Treatment. J Clin Med 2017;6:29.

43 Al-Omary FAM: Melatonin. Comprehensive Profile; in Brittain HG (ed) Profiles of Drug Substances, Excipients and Related Methodology. Academic Press, 2013, vol 38, pp 159-226. 


\section{Cellular Physiology Cell Physiol Biochem 2017;44:763-777 \begin{tabular}{l|l|l} 
DOI: 10.1159/000485290 & $\begin{array}{l}\text { O 2017 The Author(s). Published by S. Karger AG, Basel } \\
\text { www.karger.com/cpb }\end{array}$
\end{tabular}}

Chovancova et al.: Melatonin and Cancer

44 Favero G, Rodella LF, Reiter RJ, Rezzani R: Melatonin and its atheroprotective effects: A review. Mol Cell Endocrinol 2014;382:926-937.

45 Galano A, Tan DX, Reiter RJ: On the free radical scavenging activities of melatonin's metabolites, AFMK and AMK. J Pineal Res 2013;54:245-257.

-46 Ramis MR, Esteban S, Miralles A, Tan DX, Reiter RJ: Protective effects of melatonin and mitochondriatargeted antioxidants against oxidative stress: A review. Curr Med Chem 2015;22:2690-2711.

47 Wu HJ, Wu C, Niu HJ, Wang K, Mo LJ, Shao AW, Dixon BJ, Zhang JM, Yang SX, Wang YR: Neuroprotective Mechanisms of Melatonin in Hemorrhagic Stroke. Cell Mol Neurobiol 2017. DOI: 10.1007/s10571-1001710461-10579.

48 Martinez-Useros J, Garcia-Foncillas J: Obesity and colorectal cancer: Molecular features of adipose tissue. J Transl Med 2016;14:21.

49 Bishayee K, Khuda-Bukhsh AR, Huh SO: PLGA-loaded gold-nanoparticles precipitated with quercetin downregulate HDAC-Akt activities controlling proliferation and activate p53-ROS crosstalk to induce apoptosis in hepatocarcinoma cells. Mol Cells 2015;38:518-527.

50 Görlach A, Bertram K, Hudecova S, Krizanova O: Calcium and ROS: A mutual interplay. Redox Biol 2015;6:260-271.

-51 Gordeeva AV, Zvyagilskaya RA, Labas YA: Cross-Talk between Reactive Oxygen Species and Calcium in Living Cells. Biochemistry (Mosc) 2003;68:1077-1080.

52 Huai JP, Sun XC, Chen MJ, Jin Y, Ye XH, Wu JS, Huang ZM: Melatonin attenuates acute pancreatitis-associated lung injury in rats by modulating interleukin $22 \quad$ World J Gastroenterol 2012;18:5122-5128.

-53 Çelik Ö, Naziroğlu M: Melatonin modulates apoptosis and TRPM2 channels in transfected cells activated by oxidative stress. Physiol Behav 2012;107:458-465.

54 Alves E, Bartlett PJ, Garcia CRS, Thomas AP: Melatonin and $\mathrm{IP}_{3}$-induced $\mathrm{Ca}^{2+}$ release from intracellular stores in the malaria parasite Plasmodium falciparum within infected red blood cells. J Biol Chem 2011;286:5905-5912.

55 Hudecova S, Markova J, Simko V, Csaderova L, Stracina T, Sirova M, Fojtu M, Svastova E, Gronesova P, Pastorek M, Novakova M, Cholujova D, Kopacek J, Pastorekova S, Sedlak J, Krizanova O: Sulforaphaneinduced apoptosis involves the type $1 \mathrm{IP}_{3}$ receptor. Oncotarget 2016;7:61403-61418.

56 Lin S, Hoffmann K, Gao C, Petrulionis M, Herr I, Schemmer P: Melatonin promotes sorafenib-induced apoptosis through synergistic activation of JNK/c-jun pathway in human hepatocellular carcinoma. J Pineal Res 2017;62:e12398.

57 Hao J, Li Z, Zhang C, Yu W, Tang Z, Li Y, Feng X, Gao Y, Liu Q, Huang W, Guo W, Deng W: Targeting NF-кB/AP$2 \beta$ signaling to enhance antitumor activity of cisplatin by melatonin in hepatocellular carcinoma cells. Am J Cancer Res 2017;7:13-27.

\$58 Lu YX, Chen DL, Wang DS, Chen LZ, Mo HY, Sheng H, Bai L, Wu QN, Yu HE, Xie D, Yun JP, Zeng ZL, Wang F, Ju HQ Xu RH: Melatonin enhances sensitivity to fluorouracil in oesophageal squamous cell carcinoma through inhibition of Erk and Akt pathway. Cell Death Dis 2016;7:e2432.

-59 Bhat TA, Chaudhary AK, Kumar S, O’Malley J, Inigo JR, Kumar R, Yadav N, Chandra D: Endoplasmic reticulum-mediated unfolded protein response and mitochondrial apoptosis in cancer. Biochim Biophys Acta Rev Cancer 2017;1867:58-66.

60 Xue F, Shi C, Chen Q, Hang W, Xia L, Wu Y, Tao SZ, Zhou J, Shi A, Chen J: Melatonin mediates protective effects against kainic acid-induced neuronal death through safeguarding er stress and mitochondrial disturbance. Front Mol Neurosci 2017;10:49.

61 Uguz AC, Demirci K, Espino J: The importance of melatonin and mitochondria interaction in mood disorders and schizophrenia: A current assessment. Curr Med Chem 2016;23:2146-2158.

62 Reiter RJ: Mechanisms of cancer inhibition by melatonin. J Pineal Res 2004;37:213-214.

63 Mediavilla MD, Sanchez-Barcelo EJ, Tan DX, Manchester L, Reiter RJ: Basic mechanisms involved in the anticancer effects of melatonin. Curr Med Chem 2010;17:4462-4481. 